\title{
The Culture of Amateur Real Estate Investing
}

\author{
Philip ME Garboden \\ University of Hawai i at Manoa \\ Department of Urban and Regional Planning \\ 2424 Maile Way \\ Honolulu, HI 96822 \\ pgarbod@hawaii.edu
}

PRE-PRINT, BEING REVISED FOR PUBLICATION

November 2018

\begin{abstract}
* The author would like to thank Stefanie DeLuca, Kathryn Edin, Nicholas Papageorge, Tim Nelson, Anna Rhodes, and Eva Rosen for comments on this paper. The author would like to further acknowledge Meredith Grief, Barbara Kiviat, Christine Jang, Brianna Bueltmann, Noah Saganski, Ben Schwartz, and Stephan Wong for assistance with data collection and coding.

Funded by grants from the Furman Center for Real Estate and Public Policy, the Department of Housing and Urban Development, and the Annie E. Casey Foundation.

Disclaimer: The work that provided the basis for this publication was supported by funding under a grant with the U.S. Department of Housing and Urban Development. The substance and findings of the work are dedicated to the public. The author and publisher are solely responsible for the accuracy of the statements and interpretations contained in this publication. Such interpretations do not necessarily reflect the views of the Government.
\end{abstract}




\begin{abstract}
The majority of rental properties in the U.S. today is owned by small- to medium-sized investors, many of whom enter the trade with little prior experience. This paper considers the cultural factors that motivate these amateurs to purchase real estate-an investment with high risks and relatively poor returns. Drawing on in-depth interviews with 93 investors in three heterogeneous real estate markets, Baltimore, MD, Dallas, TX, and Cleveland, $\mathrm{OH}$, combined with participant observation of 22 real estate investment association meetings (REIAs), this paper finds that amateurs who decide to become investors often do so during periods when their professional identities are insecure or they perceive their retirement portfolios to be insufficient. Through participation in real estate investment associations and other investor networks, they quickly internalize "investor culture," embracing ideologies of self-sufficiency and risk. "Investor culture"-perpetuated by REIAs--motivates and legitimizes strategies of action that lead to increasingly leveraged investments. Third-party actors, including real estate gurus, paid mentors, and private "hard money" lenders exploit the intersection of insecurity and the propagation of investor culture to profit off amateurs' investment decisions.
\end{abstract}

\title{
INTRODUCTION
}

For amateurs, investing in low-end urban real estate is risky. While some are able to survive long enough to make a profit (Desmond 2016), small-scale urban landlords and property flippers operate with high levels of volatility (Brown 2004). Financial data on amateur real estate investment is limited, but the analyses that do exist suggest that the expected returns for this type of speculation are modest and inadequate to compensate for its risks (Bayer et al. 2011, Depken II et al. 2009, Garboden and Newman 2012, Mallach 2006). ${ }^{1}$ Furthermore, because amateur real estate investments are highly leveraged and often individually guaranteed, the costs of failure extend well beyond the loss of invested capital, jeopardizing the investor's credit rating and personal assets as well.

Never have the risks inherent in small-scale urban real estate investment been more manifest than during the boom and bust cycle of the 2000s. During that time, tens of thousands of amateurs began purchasing properties in America's cities where an estimated 30-50 percent of

\footnotetext{
${ }^{1}$ This finding only applies to small-scale amateur investing. Corporate large-scale investment in real estate, such as Real Estate Investment Trusts (REITs), generates fairly reliable returns (Ross and Zisler 1999, Chan et al. 1990).
} 
mortgage initiations were to investors (Haughwout et al. 2011, also Cinco and Meyer 2012, Gilberbloom et al. 2012, Rosenblatt \& Sacco 2017). When the market collapsed, many of these investors suffered substantial losses (Bayer et al. 2011, Depken II et al. 2009). This behavior, doubly deleterious to communities and the investors themselves (Treuhaft et al. 2010, Immergluck 2009), prompts a key research question: Why do amateur investors enter and persist in speculative urban real estate investing even in cases where financial returns are inadequate to compensate for risk?

To answer this question, this paper draws on in-depth interviews with 93 small real estate investors and ethnographic observations of real estate investment associations (REIAs). ${ }^{2}$ I find that the majority of investors begin to purchase real estate during periods of employment insecurity, professional dissatisfaction, and worries about retirement. I find that respondents manage the financial and emotional cost of failing to establish economic security through traditional means by adopting a new economic identity-that of the "citizen investor" (Fridman 2017, Harrington 2008, Davis 2009, Graeber 2014, Preda 2017). This identity aligns with particular cultural ideologies, readily identifiable in the media ( $c f$ Trump University) and transmitted to amateur investors via the real estate investment associations (REIAs) they belong to, the seminars they attend, the books they read, and the paid, personal mentoring that some avail themselves of. My inductive analysis of in-depth interviews with investors and fieldnotes based on my observations of REIAs and other investor-focused events, reveals an "investor culture" with three primary ideologies: 1) self-sufficiency, particularly self-employment, is a key aspect of personal well-being; 2) land and real estate is preferable to stocks, bonds, and other savings because the former are materially available and require no elite expertise; 3 ) in order to

\footnotetext{
${ }^{2}$ Throughout, the term investor includes both individuals who purchase housing for resale ("flippers") and those who purchase houses to rent (landlords).
} 
succeed, a person cannot hold back, he or she must be willing to take risks. Even when their investments prove more labor intensive and less profitable than they had hoped, amateur investors continue to utilize these ideologies to legitimate and motivate future investment behavior, even to their economic detriment.

The choice to embrace investment culture, while certainly influenced by individual predispositions (Hamilton et al. 2013), is not entirely endogenous. I find that a host of profit seeking third-party actors including real estate gurus, paid mentors, and private lenders evangelize the cultural components of real estate investing. Investor seminars hosted by the REIAs, for example, serve a dual function of information transfer and collective public celebration of the investor identity - a process I call "cultural amplification." This process serves the interests of third-party actors who manipulate investors' desire for a new economic identity to sell them additional training, recruit them for un- or low-paid labor, and lend them money at high interest rates. This process pushes some investors into highly leveraged financial positions, increasing their economic insecurity, and, in some cases, moving them towards insolvency.

By considering the role of culture in real estate investment, this paper reveals a largely unexamined factor in our understanding of how speculative housing markets become detached from market fundamentals. The data utilized here cannot provide a rigorous assessment of the long term returns of particular investments, but it can show how cultural forces impact individual perceptions of these returns and how "cultural amplification" exacerbates these misperceptions. Specifically, I argue that the cultural repertoire of investing provides non-pecuniary identity benefits to individuals for whom traditional wealth accumulation strategies, and thus traditional economic identities, have failed. When this repertoire is evangelized by individuals in a position 
to profit from the risks of others, the economic stopgap of increased prices and diminished returns can be short-circuited, with historically catastrophic results for American communities.

In making this argument, I am forced to jettison the traditional dyadic understanding of the housing market as consisting of owners and renters, of the exploiter and the exploited. In line with contemporary theories of financial capitalism, I understand the mass-expansion of the ownership class (through privatization of the social safety net) as a process of layered extraction (Davis 2009, Graeber 2014, Harvey 2017). Amateur rental property owners most certainly exploit poor tenants (Desmond 2016), but they in turn are vulnerable to exploitation from above, in the form of lending and educational services (Harvey 2017). By theorizing urban housing markets as a multi-dimensional system of value extraction, I am able to update our understanding of these economic systems to align with contemporary dynamics.

\section{Real Estate Speculation \& Housing Bubbles}

Given its inherently monopolistic nature, real estate has always been a locus of speculative investment leading to periodic boom-bust cycles (Harvey 1973, Smith 1996, Glaeser 2013, Kindleberger and Aliber 2005, Shiller 2005). And because purchases are leveraged and require no special skills, expertise, infrastructure, or credential, real estate is marketed as an opportunity for poorly capitalized individuals to generate investment portfolios far beyond what would be possible with stocks or bonds (Allen 2004). This has led to remarkable market heterogeneity, ranging from large multinational Real Estate Investment Trusts (REITs) to millions of Americans for whom homeownership represents their primary source of wealth accumulation.

Somewhere between these extremes fall the investors examined in this paper individuals that own between one and fifty investment properties, which they are either 
renovating for resale or renting. Demographically, these investors tend to be middle class, less educated than their peers, and middle aged (Shroder 2001, Ionnides and Rosenthal 1994, Wood and Ong 2013). Their class position is not easily categorized, falling somewhere between rentier and small business owner (Steinmetz and Wright 1989); while most aspire to become full time investors, the vast majority buy and sell real estate while still participating in the traditional labor market (Mallach 2006).

The economic position of small investors disallows explanations of economic behavior that rely solely on structural barriers to mainstream economic opportunities. Small real estate investors are not forced into investing, opening up key questions about why they make the decision to invest at a particular point in their lives. In his seminal work on housing bubbles, Robert Shiller identifies what he terms "cultural factors" related to housing speculation (2005:84 Shiller 1990), focusing primarily on how news media and popular culture generate inflated expectations of real estate price appreciation either directly through inaccurate forecasting or indirectly through the promotion of the idea that markets have entered a "new era" where fundamentals are no longer relevant (2005:132). For Shiller, culture is the means by which individuals acquire false expectations of investment returns, which then encourages them to over accumulate. While compelling, this account contains a fairly narrow understanding of culture, one that overlooks a significant body of social theory dedicated to understanding the cultural basis of economic action.

\section{The Cultural Basis of Economic Action}

Since Keynes' assertion that most “of our decisions to do something positive... can only be taken as a result of animal spirits" (1936 s. VII), sociologists, psychologists, and economists have attempted to systematically account for economic behaviors that cannot be explained through 
a sober quantification of expected returns (DiMaggio 2002, Kahneman \& Tversky 2000, 1984, Hamilton et al. 2013). Whether deciding where to invest one's savings or weighing the pros or cons of entrepreneurship, individuals continually make economic decisions under conditions of uncertainty. A great deal of economic theory has been devised to quantify and monetize that uncertainty - to turn uncertainty into risk (Bernstein 1997, Knight 1921). But even when risks are measurable and known, economic decisions are driven, at least in part, by a wide variety of noneconomic factors (Dequech 2003). Economic sociology offers a number of explanations for highrisk investment and small-scale self-employment including structural barriers to mainstream employment (Venkatesh 2009, Portes 1995, Yoon 1997); social stratification and networks (Grantovetter 1978, Bourdieu 2005); narrative "fictionality" (Beckert 2013, 2016); and, most relevant to this analysis, culture (DiMaggio 1990, Wherry 2012, Abolafia 1998).

The canonical articulation of how culture drives economic action is Weber's argument that cultural beliefs, norms, and values lead individuals to pursue particular economic strategies that, in turn, shape market structures (1905). As the sociology of culture has progressed, however, the field has moved beyond this macro-cultural framework of shared values, to a newer model of culture as repertoire (or tool-kit) (Spillman 1999, Swidler 1986, 2001, Lamont and Small 2008). In Swidler's classic argument, individuals use cultural repertoires to motivate, legitimate, and pursue particular strategies of action, especially during unsettled periods in their lives: "when people are learning new ways of organizing individual and collective action, practicing unfamiliar habits until they become familiar, then doctrine, symbol, and ritual directly shape action" (1986:278).

Recent work on financialization has noted that the cultural identity of the investor has become increasingly integrated into lower and middle class behavior; increasing financial 
insecurity, the casualization of employment, and the privatization of pensions has created a vast demographic of investor-citizens (Preda 2005, Davis 2009, Fligstein and Goldstein 2015). More and more economically marginal individuals have transitioned from a savings strategy to an investor strategy to pursue financial security (Leyshon and French 2009, Graeber 2014, Ailon 2015, Fridman 2016). This trend allows vulnerable populations to construct an imagined cultural community united across the economic spectrum despite vast financial inequalities (Preda 2005, Pollner 2002).

This trend suggests the emergence not only of an investor identity, but a cultural repertoire that aligns with this identity. Multi-level marketing schemes and self-help small business has long been attractive to blue collar demographics who wish achieve economic selfsufficiency (Biggart 1989). But the dissemination of neoliberal ideologies of individualism has created a financial self-help movement that promotes self-improvement through investment (Fridman 2016, McGee 2005). As Fridman argues, the investment techniques pedaled by selfhelp gurus like Robert Kiyosaki, Suze Orman, Richard Allen, and Donald Trump, are utilized by economically insecure individuals not only for financial ends, but as a broader project of selfimprovement, a "technology of the self" (2016, Foucault 1988, see also McGee 2005). These themes have recently been picked up by Preda who investigated the world of noise trading (aka day trading), an economic strategy with well document negative returns (2017). Preda found that that not only do noise traders participate in dense social communities (both online and in person), but their actions are driven more by a need for economic meaning and autonomy than a sober calculation of expected returns. Reimagining investment as consumption in this way, the choice of investment vehicle produces "utilities derived not simply from the technical or aesthetic 
qualities of goods, per se, but also from the capacity of goods to locate the self and others in the social world" (DiMaggio 1990:124).

While these agentic notions of culture as tool kit and technology fit well with the choices of insecure middle class individuals to pursue a new economic identity (Berger 1991), they neglect key questions of how individuals select between available repertoires and, critically, how these repertoires are constructed and evangelized - what Michele Lamont calls the "cultural supply side" (1992:135). If, as I argue, amateur real estate investors are utilizing a particular repertoire to motivate the economic behavior, the questions of why they select that repertoire and by whom they are encouraged to do so, remain largely unaddressed.

\section{DATA \& METHODS}

This paper uses two primarily sources of data: 1) 93 in-depth interviews with amateur real estate investors in Baltimore, MD, Cleveland, $\mathrm{OH}$, and Dallas, TX fielded between 2013 and 2015; and 2) systematic observation of 22 real estate investment association meetings in Baltimore over the summer of 2015.

\section{Interview Data Collection}

Interviews were drawn from a stratified random sample of rental property listings taken in 2013-2014. To construct the sampling frame, a team of researchers including the author, collected three months of active listings from the most common online listing services in each city and geocoded the listed address. To ensure heterogeneity, we stratified based on whether or not the property owner was actively pursuing subsidized tenants (based on the property listing), whether the address was located in high and moderate poverty tracts (above or below 20 percent poor), and the racial composition of the neighborhood (in Cleveland and Baltimore this was a black/white divide, in Dallas we split for black/white/Latino concentration). We augmented this 
random sample with a purposive sample to capture investors who were of substantive interest or did not list their rental units publically.

To enrich our understanding of speculative investment outside of the landlord sample, we supplemented these interviews with 17 respondents we met while attending real estate investment association (REIA) meetings in Baltimore, MD. As shown in Table 1, these processes combined resulted in 127 investors, 79 from the random sample, 31 from the field sample, and 17 from the REIAs. From these, 93 were identified as amateur real estate investors. These respondent's narratives form the core of this analysis. ${ }^{3}$ Two groups were excluded: property managers for whom real estate was a salaried job rather than an investment and investors with over 50 units.

\section{[TABLE 1 ABOUT HERE]}

Amateur real estate investors in Baltimore, Dallas, and Cleveland are a diverse group of people: 38 percent are women, 48 percent are black, and 40 percent are white. Over 90 percent of my sample had at least one rental property and 35 percent also identified as rehabbers (aka house flippers). As noted above, the majority most owned only a handful of properties.

Each interview lasted one and a half to three hours and focused not only on respondents' business strategies, but also their professional and personal histories. Respondents were asked to tell the "whole story" of how they became a real estate investor, what their circumstances were like at the time, whom they sought out for advice, and what drove them to purchase their first property. We discussed what they liked and did not like about their work in the formal economy, how they saw their professional and economic identities, and to describe their day-to-day routines, as well as their hopes, dreams, and anxieties for the future. When possible, interviews

\footnotetext{
${ }^{3} 71$ percent of the random sample, 74 percent of the purposive sample, and 82 percent of the REIA sample
} 
were accompanied by ethnographic observations with the investor as he or she attended to dayto-day business. During these observations, fieldworkers accompanied respondents as they toured potential investment properties, met with appraisers, managed renovations and repairs, pitched prospective buyers, and screened prospective tenants. By probing for details during the course of these activities, we were able to compare the aspirational descriptions of real estate investment presented in the interviews, to the lived experience of investing, its potentials, and its financial pitfalls.

Respondents were offered $\$ 50$ to participate. All interviews were recorded and transcribed verbatim. Respondents selected their own pseudonyms. Other potentially identifying information has been changed to preserve confidentiality.

\section{Participant Observation of Real Estate Investor Associations (REIAs)}

Over the course of 2015, the Baltimore research team, including the author, systematically observed real estate investment association meetings for the two largest REIA's in the region. Fieldworkers presented themselves as individuals interested in learning more about real estate. While fieldworkers were able to observe the larger meetings in full anonymity, their identity as students (graduate and undergraduate) at prestigious universities was often revealed in the smaller workshops. This was enough of an anomaly that the fieldworkers reported attracting special attention (generally positive) from the association leadership who offered to take them under their wings as mentees. This special status, while no doubt limiting in some ways, allowed fieldworkers to meet with potential mentors ${ }^{4}$ and accept opportunities for additional training. ${ }^{5}$

\footnotetext{
${ }^{4}$ During all private meetings, fieldworkers informed respondents of their role as researchers and received informed consent to use information collected during the mentoring process for the study. Despite this social abnormality, the relationship generally proceeded thereafter as a typical mentor-mentee relationship.

${ }^{5}$ As described in detail below, some of the practices used by investors are either illegal (such as posting "We Buy Houses Signs") or unethical (such as pursuing properties at risk of foreclosure for quick sales). Fieldworkers did not participate in such activities.
} 
All in all, fieldworkers observed 22 sessions ranging from meetings designed for first timers ("Newbie Meetings") to large hotel ballroom filling presentations by national speakers ("Main Events"). Pseudonyms are used for all participants and association leadership. Real names are used for seminar speakers and other public figures.

\section{Data Analysis and Coding}

Interview transcripts and fieldnotes from participant observation were analyzed in two stages. First, each interview was systematically coded in MaxQDA, identifying portions devoted to how the respondent got into investing, and how he or she articulated her beliefs related to her work. From these sections, themes were identified and hypotheses developed. Each document was then re-coded and placed into the categories that emerged from the broad scan.

Throughout the text, I report the number of respondents exemplifying key characteristics or themes. I use this approach primarily to establish the prevalence of a theme within my sample, and to identify conditions under which certain processes occur, rather than to make claims regarding population-level distributions (Small 2009). In this case, the number of respondents is fairly large (93) and the majority (60 percent) was selected at random with systematic stratification on observables. Internal frequencies may therefore provide some rough insight beyond the cases at hand.

When interpreting the prevalence of various aspects of the investment culture elicited in interviews and observed in REIA meetings and other events, it is important to remember that these were not probed for directly in the interview protocol. They emerged organically from discussions of my respondents' business strategies, goals, and open-ended questions regarding what motivated a particular strategy. Because cultural ideologies are, by definition, broadly available, direct probing may have induced almost all respondents to reframe their narratives in 
those terms. By not probing directly, the data reveals the frequency with which amateur investors utilized particular ideologies without prompting to explain their behavior.

\section{RESULTS}

The empirical findings are divided into four sections. The first uses interview data to discuss the forms of professional and economic insecurity that led respondents to pursue a new economic identity by pursuing real estate investing. The second describes the ideologies of investor culture using data from real estate investment seminars and associated media. The third section returns to the interview data, examining how amateur real estate investors utilize the ideologies of investing promulgated by these sources to legitimize and motivate their economic behavior. The final section of the analysis discusses the role of third-party actors in creating and evangelizing investor culture. It further describes how these processes leave small amateur investors vulnerable, as individuals in positions of authority in the investor community sell them paid training, use them for un or under-paid labor, and support their ambitions by offering private high-interest loans.

\section{Confronting Insecurity: When Amateurs Start Investing}

Of the 93 investors in the sample, 52 percent began investing during the housing bubble a period of unprecedented price appreciation. While the misinformation during this particular historical moment greatly expanded the number of amateurs purchasing investment properties (Shiller 2005), the origin stories of the investors I study suggest that individual life histories mattered as well. As shown in Table 2, respondents describe four main motivations for making their initial investment in real estate: work dissatisfaction, retirement insecurity, general interest in investment, and simple accident (generally because they moved and were unable to sell a previous residence after the market crash). 


\section{[TABLE 2 ABOUT HERE]}

Nearly half of the investors got into real estate in an attempt to exit a labor market that did not fit their needs. This mismatch took many forms, ranging from explicit struggles to find gainful employment to professional dissatisfaction. Some investors were just out of college or graduate school and were having trouble finding a job in line with their credentials. Others had toiled for years in unfulfilling white-collar employment and had become increasingly frustrated with their lack of upward mobility and wealth accumulation. And finally some, like Katherine, an African American doctoral student at the University of Phoenix who I met at a real estate investors' "newbie" meeting in Baltimore, were looking for a way out of the at-will treadmill of the low wage labor market.

Katherine had tried almost everything in search of a traditional career. She started as a realtor but soon came up against the stark hierarchies of that work:

Unbeknownst to me, I had to work long evenings and weekends and I didn't have the experience, so I became someone's assistant [and had to work a lot of hours]. And so I had to make a decision to get out of the real estate business at that time--until my children got older--but at the same time, the [real estate] market had crashed. So I had to go a different path.

She and a friend had agreed to pursue a cosmetology degree together, but at the last minute her friend had switched to real estate investing. When they met up a few years later, Katherine noticed that her friend had just purchased "a brand new Lexus, a brand new Audi" and Katherine was still "a struggling beautician, [an] educated hair stylist." So she decided to switch careers again and is now pursuing wholesale deals ${ }^{6}$ with an eye toward buying an investment property.

The second life period during which people invest is during the years just preceding retirement, represented by 18 percent of small real estate investors in my sample. Most of the

\footnotetext{
${ }^{6}$ As described in detail below, wholesaling is the process of identifying properties with motivated sellers and connecting them buyers, collecting the difference between the negotiated selling and buying price.
} 
investors in this category had held down long-term stable employment that provided a lifetime of financial security. Reflecting an increasing working and middle class trend, however, these individuals had little faith that government benefits—including Social Security and Medicareand doubted that their own retirement accounts would be sufficient to maintain their quality of life through retirement.

Beatrice, an African American woman from Baltimore with a portfolio of four singlefamily rentals, was nearing the end of a career as an IT contractor for the federal government in Washington, DC. The job paid well and Beatrice had rarely had to worry about money, but she had begun to worry about the future, "I don't have benefits or - I have a 401k but I'm not getting a pension or anything else like this and I'm almost 60 years old." Beatrice explained that the goal of owning rental properties is to provide what investors call "passive income" meaning that rent comes in from the rental properties each month without any additional work from the investor: "That's like my pension, the passive income."

For some individuals, particularly those on the cusp of retirement, the decision to invest in real estate can be interpreted as a sort of desperate gamble — - jettisoning the slow and steady returns of mainstream employment for what they believe to be the high-risk, high-return potential of real estate investment. In explaining their transitions, however, most investors avoided focusing on the risk-return tradeoff and instead described their economic decisions in ideological terms. Real estate investment provides insecure individuals not only with a novel means to make a living, but a new economic identity as well, one that comes with a pre-existing cultural repertoire. Before discussing how investors use this repertoire to motivate their economic behavior, it is first necessary to articulate its core themes, which I derived from an inductive analysis of presentations and discussions at real estate investor associations and other 
events, and in the writings of real estate gurus such as Robert Kiyosaki, Robert Allen, and Donald Trump.

\section{The Ideologies of Investing}

Within the domain of real estate investment, there exists a vast industry of books, websites, gurus, and seminars all selling an investor identity (e.g., Allen 2004, Kiyosaki 1997 , Kiyosaki 2006, Chavis 2009, Graziosi 2007, Martinez 2006). These media merge the cultural figure of the investor with the language of self-help (Fridman 2016), resulting in respondents' implicit belief that adopting not only the work of real estate investing, but its cultural features as well, is essential for personal transformation.

Real estate guru Robert Allen, whose bestselling book, Nothing Down, was recommended by several respondents, gives the following advice:

Arise an hour earlier in the morning than you usually do. This is important. The average person gets up at the last minute, eats breakfast on the run, and arrives at work in total chaos... You need to be different. Get up a bit early. In the quiet, peaceful hours of the morning, before anyone else is up, take thirty to sixty minutes to read books and articles that are related to your long term goals. One by one, as the lights come on in your neighbors' houses, and the worlds start to groan into activity, you will feel a sense of power in knowing that you are different. Normal people don't do such things - that's why they're normal. But you are special. You have the courage to change your life a little bit at a time. Slowly, day by day, you are growing. (2004:227)

While somewhat more poetic than average, Allen's quote reflects how the mundane methods of real estate investment - in this case waking up early to study-are intimately linked to a larger investor culture and, in turn, a "special" investor identity.

Investor culture is publically presented monthly at real estate investors association meetings in hotel ballrooms across the country. Investors from across each region attend to mingle, drink coffee, and hear a presentation from industry leaders, some on national speaking tours and others plucked from the association's senior membership. At a REIA in Baltimore, 
self-described "seasoned" investors Joe DiMaggio and Larry Blizzard regularly host a training called "Street-Smart Secrets for Creating Wealth and Cashflow NOW!" It's an engaging presentation, with Larry and Joe adopting a sort of Laurel and Hardy style of good natured ribbing. But the presentation begins with an emotional pitch. Joe talks about starting out in real estate in the 1990s when he, like many of my respondents, was broke. He attributes his financial insecurity to a divorce, a detail played to comic effect with the audience. He started "buying and holding" (investor speak for being a landlord), then got into rehabbing, and now does lending. This trajectory, he says, is open to all attendees. Joe lists several reasons why the audience should invest in real estate. First he highlights the financial aspects, stressing that real estate can "increase your income immediately" while also permitting "long-term wealth building." But it's more than just that, real estate is a path towards "gradual or immediate career change" and the ability to "increase your financial security." At this point Larry jumps in with a quip, "social security... more like social insecurity!" After a chuckle, Joe concludes that real estate is an investment for people "seeking autonomy in their daily decisions." "Establish your dream!" Joe implores, "what is your goal?"

The themes evident in Joe and Larry's presentation at the monthly meetings are reflected in more intimate events as well, particularly the so called "newbie" meetings that introduce first time attendees to the associations. Unlike Joe and Larry who claim to have made it big, Josephine is a herself a small time investor who sometimes struggles to finish her rehabilitations within a profitable timeframe. Her spiel to new members borrows directly from the same repertoire as Joe and Larry's, noting that the upside of real estate investment includes not only "leverage; no money down - other people's money (OPM); appreciation; tax advantages; and cash flow" but also "control over your life." Don't be held back by the amount of money you 
have to invest, Josephine encourages, there are "[private] lenders willing to loan you money." She stressed to the newbies that there are no barriers to their success, so long as they are willing to "educate themselves."

As reflected in these examples, the messages of these seminars and the books recommended and sold there are highly repetitive. My inductive coding of fieldnotes, along with the books recommended by my respondents, identified three core ideologies of investor culture: 1) self-sufficiency, particularly self-employment, is a key aspect of personal well-being; 2) land and real estate is preferable to stocks, bonds, and other savings because they do not require elite skills and can be learned by doing; 3 ) in order to succeed you can't hold back, you must be willing to take risks. Each of these was cited frequently by respondents when asked about their decision to invest in real estate.

\section{Legitimizing and Motivating Investment}

The ideologies described above are identifiable within mainstream American culture, tapping into some of our deepest national myths of self-sufficiency, populism, and economic dynamism. While some small investors likely make this connection on their own, the majority of the investors I spoke with were exposed to these ideologies through third parties. 66 percent chose to invest because a friend of family member had made a similar step, 47 percent of the respondents had a professional mentor, 31 percent mentioned reading investing books or attending courses hosted by real estate gurus, and 29 percent attended real estate investment associations. $^{7}$

\footnotetext{
${ }^{7}$ The distinction between seminars and REIAs is somewhat fluid. Generally, seminars are purchased individually and are one-off trainings or events. REIAs, in contrast, host weekly or monthly meetings. The REIA number includes respondents who were recruited from the REIAs and falls to 17 percent once those respondents are excluded.
} 
The combination of an increasingly mainstream investor culture and institutions of exogenous acculturation resulted in astonishing thematic consistency within the interview data. Table 3 presents the prevalence of each ideological component in the interviews with small investors. These cultural explanations interact with investment decisions in an iterative way; they are used retrospectively to explain a particular economic behavior but, in doing so, serve to motivate a continuation of that behavior.

\section{[TABLE 3 ABOUT HERE]}

\subsection{Self-Sufficiency and Self-Employment}

The fundamental ideology of self-sufficiency has remained a key portion of the American myth since the nation's founding. The majority of amateur real estate investors explicitly cited self-sufficiency as a core motivation for their work, linking it directly to investment. Investors believe the first step towards self-sufficiency is to exit the wage labor market. For a third of the sample, this was framed not only in aspirational terms, but was transformed to denigrate traditional employment. Gary, a middle-aged white owner of rental properties in Cleveland, had worked as an IT salesman for 15 years prior to purchasing his first investment property. By his own accounts, Gary was good at his job, often getting sizable bonuses when he exceeded his sales quotas. Gary hated the politics of this workplace, but most of all he hated the lack of "freedom:"

Well then you know with a job, your employer has this invisible chain around your neck and he starts rattling it about an hour or two before you're scheduled to come into work... And then he lets up on Friday and gives you some slack but then he starts rattling again come Sunday night. And then the rattling gets stronger and stronger come Monday when it's in full force and effect. Well, when you're in business for yourself or not dependent upon other people for money, health insurance, benefits, things like that, you don't have that rattle. 
After reading Nothing Down by real estate guru Robert Allen, Gary realized that his lack of savings was not an impediment to real estate investment. He cut the chain, formed an LLC, and purchased his first rental property.

At the core of Gary and others' stories is a sort of wealth doctrine, lifted directly from Kiyosaki's famous Rich Dad, Poor Dad series: wealthy people use their money to make money rather than working for it (1997). Real estate culture celebrates the idea that to work all the time is to be a dupe - and that the focus should be on the "passive income" that comes from investment. Joan, a former nonprofit manager who invested in Baltimore rental properties for her "dotage," sums up the distinction between being a landlord - who oversees the day-to-day of an investment portfolio - and an investor who outsources this work:

Well, it's funny because I am a landlord, but I don't wanna be a landlord. I don't want my focus to be on the repairs and the screening people and all of that. I want my focus to be at this age... I realize I want to live in Hawaii for part of the year and so, that is going to take more income than if I had just like kept those two properties... So I will need to have property managers. To me then, that becomes different than being a landlord.

Of course, the reality for almost all amateur investors is far removed from this ideal. Most cannot afford a manager and thus work many more hours than the typical nine-to-five - responding to the needs of contractors and tenants on evenings and weekends.

Investors are able to overlook this contradiction because the work they put into growing and sustaining their portfolios provides them with cultural and identity benefits above and beyond the financial returns. While they are working on their investments, they are simultaneously building towards a new economic identity free from the vicissitudes of the labor market. The goal, as Gary put it, is to enter a place where "you're not worried about down economies or up economies because the economy is always up for you."

\subsection{Land as Material \& Anti-Elitist}


For investors looking for self-sufficiency, the natural question is why they chose to invest in real estate rather than more secure (and indeed passive) investment vehicles. When answering this question, investors focused on cultural rather than material explanations: stocks represent an alien and elitist form of investment, to which things happen for no apparent reason, whereas real estate is something you can touch and control. As Jack Howard, who had run a document management company with his wife before their divorce forced him to divest himself from the tech business, put it,

And I thought that stocks - real estate gave me more control; direct control over the assets, versus stocks were very up in the air. You have to do a lot of research. And so random events... If the CEO gets sick or scandaled [sic] or the market changes over night and products or services is no longer needed... Real estate was the best use of my time and money...

Of course, investors could put their money in index funds or annuities and have relative confidence that their savings were not simply going to disappear overnight. They avoid this for two reasons. First, the returns on safe investments are limited, slow, and steady, preventing the investor from envisioning life without work in the near future and the corresponding identity benefits described above. But the respondents were also seeking an investment vehicle that exists in a material sense, one that harmonizes with the most basic vision of self-sufficiency in America: land. As Frederick, a middle aged white man who teaches courses at a Baltimore investor association put it, land is "a source of wealth in this county," land means "independence" and "that's appealing to a lot of people."

The idea that real estate is something "you can touch" adds a sense of security to amateur investors who can be fairly sure that the property, if not its value, will not disappear overnight. But, unlike stocks, it also requires an expertise that can be learned on the job. This practical consideration takes on cultural value in respondents' narratives. Ben Roth, the fast talking owner 
of several dozen low-quality Baltimore row houses, compared my education to his own when I met him for lunch, "I know coming out of [school], you're worried about how to make money...you're smarter than I am because you're doing the [school]. I went to the School of Hard Knocks.” Ben spoke these words with pride and a hint of derision directed at my more mainstream choices. His quote taps into the populist cultural ideology that bootstrapping to economic expertise is not only possible, but desired. By aligning their inexperience with this cultural narrative, an apparent education deficit is translated into a strength.

\subsection{Risk \& Success}

Even though the interviews were all conducted in the wake of the housing market collapse, 48 percent of the respondents expressed an explicitly "why not?" attitude towards risk and debt. These investors not only purchased investment properties with limited due-diligence, but embraced this relentless hustle and optimistic accumulation as a key part of the investor identity. Zena, a former real estate agent from Dallas who specializes in renting to voucher families, describes her first rental purchase.

The first house I purchased for myself... I just said, "Lord, bless me with a fixer-upper. I don't want to have to pay a whole lot of money for a house. Bless me with a fixer-upper with a lot of land around..." So I kept looking and I kept looking and I said, "Okay Lord, I'm waiting on you." I keep looking and kept looking cause I can't just stand still, I gotta do something.

Here Zena is very explicit about her rush to assume the investor identity - a push that in her case was placed in her religious faith. As Harrington (2008) points out, in order for an individual to assume the identity of an investor, she must necessarily perform the act of investment. Those who hold back on acquiring investment real estate must also defer the desired identity transformation. 
In order to defend this behavior, respondents looked into the future with optimism. The failures of the past are considered as lessons learned the hard way, never to be repeated. When probed about the recent collapse of the market, many investors argued that you could make money in any market, you just needed to have the right strategy. Or as Molly, a Cleveland investor, put it, "Winners win, only losers lose right?" Kendra, who purchased her first home at the age of 17 , expressed this undying optimism using highly impassioned rhetoric:

I encourage people if they can purchase and buy some property, why not? That's what it's here for. I believe it's a great tax shelter. So yeah I encourage that to anyone. I tell everyone I don't want to be the only rich one around. Join me. I tell everybody that. I should be able to have other friends that whenever I need something I come to you because I'm short this month. It's nice, so why not?

Kendra's "why not?" attitude represents a sort of shared mythology among investors that what separates individuals from financial security is primarily fear, rather than structure or circumstance. Even if ill-advised, the act of investing, of assuming the investor identity, takes on symbolic value for the investors, who believe it is the first step to stability.

But these emotional benefits are counterbalanced by real costs. Samantha got into real estate at the height of the bubble. A social worker and nascent empty nester, she reflected how thrilling it was to be "joining the business world and getting involved in something that seemed so exciting." She wanted to retire and, in her words, to "undo" getting a job: "You know, you read in any of those books that what's his name, Rich Dad, Poor Dad, that's the wealth... Buy and hold [aka landlording] is where the wealth is built."

The son of a friend of hers approached her with the opportunity to buy three properties for $\$ 90,000$ in a high-poverty neighborhood in Baltimore. It seemed like a good deal, at least based on the numbers he showed her, but Samantha "didn't know what she didn't know." She nonetheless put down $\$ 3,000$ as down payment. Even when experienced investors told her it was 
a bad deal, that she should lose the $\$ 3,000$ and get out, Samantha persisted. After several years of fighting with tenants and property managers, Samantha finally sold the properties at a substantial loss to a friend she'd met at a real estate meeting who liked "warzone" properties. Samantha says "I lost money all the way through, but now I'm even more determined to stick with it. I've learned a lot of lessons." Samantha joined a mentoring group at a local investors association, dug into her savings and reinvested, with better, albeit not ideal results: "Now, did I pay too much? Yes. Did I rehab too high? Yes. Do I have cash flow? No, but at least it's not a headache."

At each point, Samantha is motivated by her desire to assume a new, more "exciting," identity as an investor, embracing portions of landlord culture, such as Kiyoski's wealth doctrine to explain her poor choices. But Samantha's story is also full of other people - her friend's son who sold her the bad properties, the friend at the REIA who took the properties off her hands at a loss, and the new mentorship group she'd just joined. All of these actors represent how complex power dynamics within the investor community intersect with culture in deleterious ways.

\section{Cultural Amplification, Profit, and the Cultural Supply Side}

To this point, I have argued that economic insecurity intersects with the culture of investment to encourage amateurs to enter and persist in speculative real estate investment. But where do these ideologies come from, how are they disseminated, and why do they have such staying power? For the majority of respondents, the investor repertoire is directly linked to an industry of real estate seminars, books, and training. This media, in and of itself, is fairly benign. The cultural component of real estate investing pushes some individuals into investing too much too soon, but it simultaneously provides significant emotional and identity benefits. Investors like Katherine spoke with pride about jettisoning the identity of "struggling beautician" and adopting that of "newbie investor." In addition, real estate associations are attended by a core of 
frequent flyers for whom the meetings provide not only entertainment, but a social community at well.

But the data suggest another, more deleterious, story of profitmaking from rather than by investors. The professional insecurity of many amateur investors makes them vulnerable to individuals who offer access to an investor identity, in exchange for their time and money. The process generally plays out as follows: First, an individual hoping to learn more about real estate investment becomes connected to a broader community by attending a training or connecting with a mentor. Through these gateways, small investors encountered lenders, paid gurus, and service providers in a position to profit from their risky accumulation of real estate. In this section, I describe how third-party actors exploit the link between investment culture and investment strategies by a process that I term "cultural amplification." Rather than direct coercion, these individuals influence small investors' behavior simply by highlighting cheerleading - an existing set of ideologies that intersects with investors' social and material vulnerability. Because real estate investing aligns material, cultural, and self-help motivations, amateur real estate investors can be deeply influenced by actors who put themselves in a position to profit by selling mentorship, extracting unpaid labor, and lending money.

\subsection{Selling the Dream: Real Estate Investment Associations}

Any given REIA will offer a wide variety of seminars, meetings, and workshops including introductory "newbie" meetings, special groups of women investors, seminars on landlording, flipping, and so forth. In some case the leaders offer special paid course packages designed to be more intensive. REIAs host monthly meetings for the entire association which host local and national speakers. The following fieldnotes from a 2015 REIA meeting sum up the style of these "main events:" 
Lou Brown [the national speaker] comes out wearing a suit, a bright pink shirt underneath, a multicolored tie, and a huge smile, his hands outspread. "How's everybody doing tonight?" he grins. "Fantastic!" a few yell amid the usual buzz of good's and great's. "That's my favorite thing," he says, "when anybody asks me how I'm doing, I say 'Fantastic!' How many of you have seen me before?" A few hands are raised. "Yeah, baby!" he grins. "Tonight," he says, we're going to have a "complete other conversation," "different from other folks." "Be ready for that," he says. "I'm an innovator. I see the gaps and the holes and fill in that niche. How many of you like that?" The loud man in the back yells, "Amen!" Lou Brown grins, "Yeah, baby! How many wanna earn money right now?" Hands shoot up and murmurs of consensus in the crowd. "Yeah, baby!"

Lou's presentation continued for about an hour but did not become appreciably more substantive. The national speakers we observed were generally vague on specifics and spent the bulk of their time pitching books and other seminars that promised to answer the questions in more depth.

The smaller seminars, hosted by local real estate professionals are more substantive. For example, one guest speaker, Jeff Donaldson, was a CPA and spoke at length to the group on the tax implications of real estate investing. In addition to extended pitches for his own services, Jeff provided a group of attentive investors with a variety of tips related to claiming business write offs. But despite his best attempts, Jeff's advice fell flat with the group. Given the applied skills necessary for real estate investment, lecturers like Jeff were either too broad to be useful without further research or too specific to apply to most cases. After just a month of observations, the field team was collecting very little new factual information about investing. And yet, despite the incredible amount of information recycling, we observed many investors attending these meetings religiously over the course of our observations.

The observational data suggest that these seminars serve two functions beyond actual information transference. The first is that the REIA provides space for networking. Investors attend REIAs with stacks of business cards and are looking for individuals to partner with or hire. The local meetings generally included a dedicated time for "quick pitches" whereby individuals would come to the front of the room and share with the group what they had to offer. 
Contractors pitched their services to flippers. Private lenders described their lending terms to flippers and landlords. Property managers pitched their business to landlords.

But second and more importantly, presentations that appeared performative and repetitive to individuals outside the group were inspiring and reaffirming to individuals who have embraced the cultural repertoire of investing. At a fundamental level, the presentations we witnessed were not about passing along technical skills, but instead served as pep rallies for an identity, coaxing those on the margin into the group, and deepening the convictions of those already on the inside. In ways reminiscent of Iddo Tavory's description of the dense social worlds of Orthodox Judaism as a continued process of summoning members into their faith (2016), the associations exist to reaffirm their members' identities as investors. Participants are continually reminded of their shared culture both through the seminars directly, but also through the emails, workshops, and websites that accompany them.

Importantly, this cultural amplification is also profitable to those who are in charge: every REIA meeting ends with a sales pitch for books, seminars, or personal one-on-one training. REIAs do a careful job of linking the aspirations of investors to their organization- a standard implementation of institutional self-promotion. The institutions themselves are not the primary beneficiaries of amateur investor's enthusiasm. The REIAs are full of more seasoned real estate professionals looking to form profitable relationships.

\subsection{With Friends Like These: Bird Dogging, Wholesaling, and Hard-Money Lending}

While the main event is happening in the middle of the room, the participants are surrounded on all sides by vendors, mostly lenders and property managers, who pay the association for booth space. Mingling with the crowd before and after the presentation are seasoned real estate investors, many of whom have transitioned into private lending, who market 
their mentorship and financing services. In all these ways, the social spaces of REIAs are full of individuals excited to encourage newbie real estate investors by profiting off them, either by lending them money, using them as unpaid labor, or by simply selling them additional training. Given the substance of the events - periods of celebratory cultural amplification - these actors are able to approach small investors at a time when their culture ideologies are at their peak.

In some cases, would-be mentors charge their mentees, generally hundreds of dollars, for the privilege of being shown the ropes. Carolyn, a soft-spoken middle-aged African American woman whose investments in Baltimore have proved devastatingly unprofitable, described a distinct demographic mismatch between herself and her paid mentor:

I remember being with him, and I'm in there trying to get information, and I guess the way that I carried myself just wasn't one that looked like [he needed] to pay attention to. And, for him... I mean [he] was just a white guy - very confident - black tie, suit. He just walked up and just started talking to [potential clients], and they started handing him stuff. So, and I guess the idea behind that was that you need to become more like [him].

The mentor perhaps felt that modeling a businessman's confident swagger would help the more reserved Carolyn succeed, but she wanted actual information on how to evaluate deals. Carolyn described this experience as nothing but a waste of money.

My fieldworkers were also identified as newbies and received offers to provide labor in exchange for mentorship. The main vehicles for such labor were serving as deal-finders (known as "bird dogs") for larger investors. This process involves using public sources of information to identify properties that could be purchased at a discount. There are a number of techniques that investors use to find properties all of which are low-yield and fairly labor intensive. The most popular is the hanging of so-called bandit "We Buy Houses" signs on telephone poles in areas where people may be motivated to sell. These signs are illegal in most jurisdictions and are rapidly removed by sanitation workers, so they must be constantly refreshed. Investors also sit in 
on housing court proceedings looking for landlords who have just gone through an extended eviction process or are being assigned rent escrow. They approach these frustrated owners offering to take their property off their hands. In some cases, they even scour lists of divorce cases and foreclosure filings trying to find potential sellers (although legislation has limited their legal access to owners facing foreclosure).

For any of these techniques, the work is very time intensive and few large investors do it themselves. They actively recruit and sometimes compete over newbies, who lack the capital or experience to invest directly. One of my fieldworkers, a white college senior, was approached by Leanne, one of the vice presidents of a local REIA, who offered to take her under her wing, challenging her to "do her first deal" before the end of the summer. To this end, Leanne assigned the fieldworker the task of sending out over 350 form letters to the owners of distressed properties in the Baltimore area, scraped from public records. This meant spent setting up a mail merge, printing letters and mailing addresses, folding and mailing. Leanne did not offer to cover the costs of supplies, postage, or printing. From the 350 letters that she sent, the fieldworker received exactly one response, from another investor hoping to unload a property and asking far more than Leanne thought reasonable. Had a deal gone through, the fieldworker had been promised a finder's fee with the bulk of the money going to Leanne who planned to sell the deal to another investor to either flip to rent out. In order to attain the status of an investor, newbies perform the leg work of the economic system at a discount, hoping to one day achieve the status of a seasoned investor like Leanne.

This process, while self-interested, is itself fairly benign-most professions require a certain amount of "paying one's dues" in exchange for access. But this power imbalance becomes pernicious when it comes to lending. Because these data were collected after 2010, 
many of the institutional lending sources that had proliferated during the housing bubble had either gone bankrupt or were forced out by regulatory adjustments. This meant that real estate investors increasingly needed to rely on private, or hard-money lenders, several of whom were interviewed as part of the ethnographic work. The value of hard-money lending - a short term, but very high interest private loan - is that it provides renovation financing to cover the difference between the appraised value of a dilapidated house and what needs to be invested into the property in order to get it ready for rental or resale. In an ideal scenario, the hard-money lender gets repaid in full as soon as the house is renovated and either sold or refinanced with a traditional loan. This means that rates for hard-money are substantially higher than traditional mortgage rates (ranging between 12-16 percent plus points). If the renovation experiences delays or if the investor is unable to refinance, the costs of debt service on a property can have profound impacts on profitability.

This was the case for Josephine, a middle-aged white woman in Baltimore introduced earlier, who decided to become a real estate investor after a failed marriage left her broke and with few marketable skills. Faced with economic insecurity and a fractured identity, Josephine threw herself entirely into real estate. Over the last decade, she struggled mightily to become a successful investor, sometimes coming to the precipice of bankruptcy. When I visited her investment properties, she talked about being months behind with the renovations, cutting sharply into her estimated profits. Because she was so devoted to her new identity, however, she pushed through, expressing unflinching optimism that each year would be better than the last. She not only embraces the work of investing, but its cultural repertoire as well, celebrating her self-sufficiency and entrepreneurial drive: "I don't have a J-O-B! I work really hard and I like 
working hard and, but, here's the beauty of it... I don't have, on any given day, if I choose to not work, I don’t have to.”

While many of her missteps were due to inexperience, a number of actors enabled her insecurity. Josephine is a fervent REIA attendee and many of the friends she has made at those meetings stood in a position to profit from taking a "green newbie" under their wing. As Josephine described it: "I aligned myself with some wrong people in the beginning. So, no. I kind of, like, did the school of hard knocks... there are, there are some vultures that just want to pounce on new people. And they make a business of it. And it's very sad, but they're out there."

The primary "vulture" relationships that Josephine is referencing are the hard-money lenders who provided her high-interest short-term loans. When I asked Josephine how she financed her deals she always said friends lent her the money, friends whom she'd met at the REIA meetings. When the market crashed, Josephine was left holding a few of these highinterest notes, which she could no longer refinance because they exceeded the market value of the home. Rather than simply foreclosing, her "lender friend" allowed her to refinance at a rate over 10 percent, which she now pays to him monthly, undermining any chance of positive cash flow on the properties.

While hard-money lenders legitimize their high rates by noting that their loans are uncollateralized, they structure their deals to minimize their own risk. They do not, for example, provide their loans up front, but like most construction loans, release them in portions as renovations proceed, thus ensuring that if they do need to foreclose, the property has some value. And more importantly, their ability to receive repayment does not depend on the investor's ability to profit from the investment, but simply the after-renovation value of the property (ARV) at which the investor can refinance with a traditional lender. Because the timeframe is limited 
and the amount of renovation predetermined, private lenders are able to predict with relative confidence what a property will be appraised for a few months later after a carefully monitored amount of work is put in. They absorb almost none of the risk associated selling a property, collecting rent receipts, vandalism, or lead paint litigation, which remain squarely with the investor. Because the hard-money lender gets in and out of these deals quickly, they operate very much like subprime mortgage originators whose primary incentive is to amplify investment regardless of the soundness of the purchase. In this way, hard money lenders depend on newbie investors to whom they can lend the money, and look for them at REIA events where they are most enthusiastic about assuming an investor identity.

\section{DISCUSSION \& CONCLUSION}

Amateur real estate investors get into investing as a rejection of traditional means to economic success, either because of job dissatisfaction or due to the realization that they were not adequately prepared for retirement. Given their unsettled positions, the respondents quickly internalized not only the practical skills involved in investing, but the "investor culture" as well embracing the ideologies of self-sufficiency, independence, and risk-taking. These scripts motivate and legitimize strategies of action that lead to additional investments regardless of whether or not those decisions are financially prudent. While some of these small investors would likely have invested in highly leveraged real estate on their own, I find that many were pushed by third-party actors.

This analysis builds off a long tradition of sociological understanding of economic decision-making. Like others, I have argued that culture plays a prominent role in the decisions of individuals to pursue particular financial strategies (DiMaggio 1990, Wherry 2012). I extend previous work by illustrating how institutions and third-party actors are able to use culture for 
profitmaking. Instead of (or in addition to) implementing programs of material coercion, misinformation, and social leverage, profit-seeking actors are able to shape the behavior of individuals by promoting an investment culture. Prescribed cultural repertoires are transmitted through books, media, and routine celebrations of the key ideologies of the investment culture what I call "cultural amplification." Real estate gurus, mentors, and lenders do not need to actually change anyone's minds about risk, they simply need to align the desired action with preexisting cultural ideologies which they themselves propagate over time.

This analysis offers an important addendum to the agentic paradigm of how culture shapes action, which has been criticized for its imprecision regarding how people choose between a myriad of available repertoires (e.g. Lamont 1992, Berger 1991). My findings suggest that imbalanced power dynamics within social and professional networks can provide an exogenous influence on the ideologies individuals choose to employ in particular contexts. While investor culture would certainly be appealing to investors independent of outside intervention, the fact that it is so routinely reinforced by institutions and individuals who are perceived as gatekeepers to an identity, challenges the application of the word "voluntary" to their decisions to take up investment culture.

The role that exogenous institutions and actors play in manipulating investors like Josephine is critical for understanding the adoption of high-risk speculative behavior. Because the power imbalance of this manipulation results in an unequal sharing of risk, cultural amplification can push individuals undertaking a high risk economic strategy, such as investment real estate, into extreme levels of leverage - reproducing the insecurity that the investor identity was intended to resolve. The fact that predatory actors exploit both the structural and cultural 
motivations for real estate investment, all while minimizing their own risk, explains one piece of why markets spiral out of control.

This suggests the need for a more complex understanding of urban housing markets than the traditional dyadic antagonism between owner and renter, between landlord and tenant (Desmond 2016). Real estate investment is a very visible example of the vast project to push more and more individuals into the position of insecure self-entrepreneurialism where risk and debt are democratized to the point that everyone is simultaneously the exploiter and the exploited (Davis 2009, Graeber 2014, Harvey 2017). As Harvey reminds us, “it becomes harder and harder to put a face to the class enemy while the tentacles of indebtedness spread far and wide to implicate everyone who carries as much as a single credit card in the pocket" $(2017$, p. 81$)$. Many of the amateur landlords in the sample described business practices that were deleterious to tenant well-being, but few felt fully in control of their behaviors, linking them to their own need for economic security.

The cyclical booms and busts of inner city real estate speculation have dire consequences for two demographics: poor renters and the speculators themselves. The potential effects of speculation on poor renters has been well described, first driving up rents and then leading either to displacement or to successive waves of abandonment and divestment in already struggling communities (Smith 1996, Treuhaft et al. 2010). Less sympathetic perhaps, but no less important, are the effects of the crash on the lives of the amateur investors. As described in the analysis section of this paper, many investors are economically insecure and the collapse of the bubble represented an enormous wealth stripping from the working and middle classes. Some of my respondents persevered long enough to be successful, but those who lost properties in the wake of the collapse, described lives of financial insecurity, sometimes weeping openly as they 
reflected on their financial missteps. These behaviors are not isolated to a particular moment. Even in the wake of the foreclosure crisis, amateurs continued to invest (Immergluck and Law 2014), with a substantial amount of disagreement regarding the benefits of passing real estate owned (REO) inventory to non-owner occupants (Herbert et al. 2013, Urban Strategies Council 2012, Treuhaft et al. 2010, Lambie Hanson et al. 2015).

Understanding the cultural factors behind real estate speculation is essential to preventing a reoccurrence of the housing bubble's excess. First and foremost, because many investors purchased rental properties during the bubble out of concerns with job and retirement security, pursing policies designed to stabilize employment, provide a living wage, and support retirement savings will likely have housing market stabilization effects as well. Secondly, when speculative bubbles begin to emerge, it is important for policymakers to take seriously the ways that thirdparty actors can use culture to spur risky accumulation. While consumer protection and lending disclosure laws exists to protect homeowners (however poorly designed they may have been), the world of private lending is almost entirely unregulated. Indeed, it hardly seems a policy priority to protect real estate investors from themselves - but the costs of this lacuna are high. 


\section{Works Cited}

Abolafia, Mitchel Y. 1998. "Markets as Cultures: An Ethnographic Approach." The Sociological Review 46(S1):69-85.

Allen, Robert G. 2004. Nothing Down for the 2000s: Dynamic New Wealth Strategies in Real Estate. New York, NY: Simon and Schuster.

Ailon, G. 2015. Rethinking calculation: the popularization of financial trading outside the global centres of finance. Economy and Society, 44(4), 592-615.

Bayer, Patrick J., Christopher Geissler, Kyle Mangum, and James W. Roberts. 2015. Speculators and Middlemen: The Strategy and Performance of Investors in the Housing Market. Rochester, NY: Social Science Research Network.

Beckert, Jens. 2013. "Imagined Futures: Fictional Expectations in the Economy." Theory and Society 42(3):219-40.

Beckert, Jens. 2016. Imagined Futures Fictional Expectations and Capitalist Dynamics. Cambridge, MA: Harvard University Press.

Berger, B. M. (1991). Structure and Choice in the Sociology of Culture. Theory and Society, 20(1), 1-19.

Bernstein, P. L., \& Boggs, J. 1997. Against The Gods. Simon \& Schuster.

Biggart, Nicole Woolsey. 1989. Charismatic Capitalism: Direct Selling Organizations in America. Chicago: University of Chicago Press

Bourdieu, Pierre. 2005. The Social Structures of the Economy. Cambridge, MA: Polity Press.

Brown, Roger J. 2004. "Risk and Private Real Estate Investments." Journal of Real Estate Portfolio Management 10(2):113-27.

Camerer, Colin and Dan Lovallo. 1999. "Overconfidence and Excess Entry: An Experimental Approach.” The American Economic Review 89(1):306-18.

Chan, K. C., Patric H. Hendershott, and Anthony B. Sanders. 1990. "Risk and Return on Real Estate: Evidence from Equity REITs.” Real Estate Economics 18(4):431-52.

Chavis, B. M. 2009. Buy It, Rent It, Profit!: Make Money as a Landlord in ANY Real Estate Market. Simon and Schuster.

Chinco, Alex, and Chris Mayer. 2012. "Distant speculators and asset bubbles in the housing market." Columbia Business School mimeo, April 2012.

Davis, G. 2009. Managed by the Markets: How Finance Reshaped America, New York, Oxford University Press.

Depken II, Craig A., Harris Hollans, and Steve Swidler. 2009. "An Empirical Analysis of Residential Property Flipping." The Journal of Real Estate Finance and Economics 39(3):248.

Dequech, D. (2003). Conventional and unconventional behavior under uncertainty. Journal of Post Keynesian Economics, 26, 145-168.

Desmond, Matthew. 2016. Evicted: Poverty and Profit in the American City. 1 edition. New York, NY: The Crown Publishing Group.

DeMiaggio, Paul. 1990. "Cultural Aspects of Economic Action and Organization," pp. 113-36 in Beyond the Marketplace: Rethinking Economy and Society, ed R. Friedland and A.F. Robertson. New York: Aldine de Gruyter.

DiMaggio, Paul. 2002. 'Endogenizing 'animal Spirits': Toward a Sociology of Collective Response to Uncertainty and Risk." Pp. 79-100 in The New Economic Sociology: 
Developments in an Emerging Field, edited by M. Guillén, R. Collins, P. England, and M. W. Meyer. New York: Russell Sage.

Fligstein, Neil and Adam Goldstein. 2015. "The Emergence of a Finance Culture in American Households, 1989-2007.” Socio-Economic Review 13(3):575-601

Foucault, M., Martin, L. H., Gutman, H., \& Hutton, P. H. 1988. Technologies of the self: A seminar with Michel Foucault. Univ of Massachusetts Press.

Fridman, D. 2016. Freedom from Work: Embracing Financial Self-Help in the United States and Argentina. Stanford University Press.

Garboden, Philip M. E. and Sandra Newman. 2012. "Is Preserving Small, Low-End Rental Housing Feasible?" Housing Policy Debate 22(4):507-26.

Gilderbloom, John I., Joshua D. Ambrosius, Gregory D. Squires, Matthew J. Hanka, and Zachary E. Kenitzer. 2012. "Investors: The Missing Piece in the Foreclosure Racial Gap Debate." Journal of Urban Affairs 34(5):559-82.

Glaeser, Edward L. 2013. A Nation Of Gamblers: Real Estate Speculation And American History. National Bureau of Economic Research.

Graeber, David. 2014. Debt - Updated and Expanded: The First 5,000 Years. Melville House.

Granovetter, M. (1978). Threshold models of collective behavior. American Journal of Sociology, 83(6), 1420-1443.

Graziosi, Dean. 2007. Be a Real Estate Millionaire: Secret Strategies to Lifetime Wealth Today. Dean Graziosi Inc.

Hamilton, Barton H., Nicholas W. Papageorge, and Nidhi Pande. 2014. The Right Stuff? Personality and Entrepreneurship. Rochester, NY: Social Science Research Network.

Harrington, Brooke. 2008. Pop Finance: Investment Clubs and the New Investor Populism. Princeton: Princeton University Press.

Harvey, David. 1973. Social Justice and the City. Athens, GA: University of Georgia Press.

Harvey, David. 2017. Marx, Capital, and the Madness of Economic Reason. Oxford University Press.

Haughwout, Andrew, Donghoon Lee, Joseph S. Tracy, Van Der Klaauw, and Wilbert. 2011. Real Estate Investors, the Leverage Cycle, and the Housing Market Crisis. Rochester, NY: Social Science Research Network.

Herbert, Christopher E., Lauren Lambie-Hanson Irene Lew Rocio Sanchez-Moyano. 2013. The Role of Investors in Acquiring Foreclosed Properties in Boston. Washington, DC: What Works Collaborative Report.

Holland, Megan M. and Stefanie DeLuca. 2016. "'Why Wait Years to Become Something?' Low-Income African American Youth and the Costly Career Search in For-Profit Trade Schools." Sociology of Education.

Immergluck, Dan. 2009. Foreclosed: High-Risk Lending, Deregulation, and the Undermining of America's Mortgage Market. Ithaca, NY: Cornell University Press.

Immergluck, Dan and Jonathan Law. 2014. "Investing in Crisis: The Methods, Strategies, and Expectations of Investors in Single-Family Foreclosed Homes in Distressed Neighborhoods." Housing Policy Debate 24(3):1-26.

Ioannides, Yannis M. and Stuart S. Rosenthal. 1994. "Estimating the Consumption and Investment Demands for Housing and Their Effect on Housing Tenure Status." The Review of Economics and Statistics 76(1):127-41. 
Kahneman, D., \& Tversky, A. 1984. Choices, values, and frames. American Psychologist, 39(4), 341.

Kahneman, D., \& Tversky, A. 2000. Choices, values, and frames. Cambridge University Press.

Keynes, J. M. 2016. General theory of employment, interest and money. Atlantic Publishers \& Dist.

Kindleberger, Charles P. and Robert Z. Aliber. 2005. Manias, Panics and Crashes: A History of Financial Crises, Fifth Edition. Hoboken, NJ: John Wiley \& Sons.

Kiyosaki. R.T. 1997. Rich Dad Poor Dad: What The Rich Teach Their Kids About Money That the Poor and Middle Class Do Not! Plata Publishing.

Kiyosaki, K. 2006. Rich Woman: A Book on Investing for Women, Take Charge Of Your Money, Take Charge Of Your Life. Rich Press.

Knight, F. H. (1921). Risk, uncertainty and profit. New York: Hart, Schaffner and Marx.

Lambie-Hanson, Lauren, Christopher E. Herbert, Irene Lew, and Rocio Sanchez-Moyano. 2015. "Foreclosed Property Investors in a Strong Housing Market City: A Case Study of Boston." Cityscape 17(2):239-68.

Lamont, Michèle. 1992. Money, Morals, and Manners: The Culture of the French and the American Upper-Middle Class. Chicago, IL: University Of Chicago Press.

Lamont, Michele and Mario L. Small. 2008. "How Culture Matters: Enriching Our Understanding of Poverty." Pp. 76-102 in The Colors of Poverty: Why Racial and Ethnic Disparities Persist, edited by A. Linn and D. Harris. New York: Russell Sage Foundation.

Leyshon, Andrew and Shaun French. 2009. “'We All Live in a Robbie Fowler House': The Geographies of the Buy to Let Market in the UK." The British Journal of Politics \& International Relations 11(3):438-60.

Mallach, Alan. 2006. "Landlords at the Margins Exploring the Dynamics of the One To Four Unit Rental Housing Industry."

Mallach, Alan. 2010. Meeting The Challenge Of Distressed Property Investors In America's Neighborhoods. New York, NY: LISC.

Martinez, Matthew. 2006. 2 Years to a Million in Real Estate. McGraw-Hill Education.

McGee, M. (2005). Self-help, Inc.: Makeover culture in American life. Oxford University Press.

Pollner, M. (2002). Inside the Bubble: Communion, Cognition, and Deep Play at the Intersection of Wall Street and. Virtual Society?: Technology, Cyberbole, Reality, 230.

Portes, A. (Ed.). (1995). The economic sociology of immigration: Essays on networks, ethnicity, and entrepreneurship. Russell Sage Foundation.

Preda, A. 2005. "The Investor as a Cultural Figure of Global Capitalism," in The Sociology of Financial Markets, ed. Karin Knorr Cetina and Alex Preda, Oxford: Oxford University Press, 141-62.

Rosenblatt, P., \& Sacco, S. J. (2017). Investors and the Geography of the Subprime Housing Crisis. Housing Policy Debate, 1-23.

Ross, Stephen A. and Randall C. Zisler. 1991. "Risk and Return in Real Estate." The Journal of Real Estate Finance and Economics 4(2):175-90.

Shiller, Robert J. 1990. "Speculative Prices and Popular Models." The Journal of Economic Perspectives 4(2):55-65.

Shiller, Robert. 2005. Irrational Exuberance, Second Edition. Princeton, NJ: Princeton University Press. 
Shroder, Mark. 2001. "What Makes a Landlord? Ownership of Real Estate by US Households." Urban Studies 38(7):1069-81.

Small, Mario L. 2009. “'How Many Cases Do I Need?' On Science and the Logic of Case Selection in Field Based Research." Ethnography. 10(1): 5-38.

Smith, Neil. 1996. The New Urban Frontier: Gentrification and the Revanchist City. London; New York: Routledge.

Spillman, L. (1999). Enriching exchange: Cultural dimensions of markets. American Journal of Economics and Sociology, 1047-1071.

Steinmetz, George and Erik Olin Wright. 1989. "The Fall and Rise of the Petty Bourgeoisie: Changing Patterns of Self-Employment in the Postwar United States." American Journal of Sociology 94(5):973-1018.

Swidler, Ann. 1986. "Culture in Action: Symbols and Strategies." American Sociological Review 51(2):273-86.

Swidler, Ann. 2001. Talk of Love: How Culture Matters. Chicago, IL: University of Chicago Press.

Tavory, Iddo. 2016. Summoned: Identification and Religious Life in a Jewish Neighborhood. Chicago, IL: University Of Chicago Press.

Treuhaft, Sarah, Kalima Rose, and Karen Black. 2010. When Investors Buy Up the Neighborhood: Preventing Investor Ownership from Causing Neighborhood Decline. Oakland, CA: PolicyLink.

Urban Strategies Council. 2012. Who Owns Your Neighborhood: The Role of Investors in PostForeclosure Oakland. Urban Strategies Council Report.

Venkatesh, Sudhir. 2009. Off the Books: The Underground Economy of the Urban Poor. First Edition edition. Cambridge, MA: Harvard University Press.

Viscelli, S. 2016. The Big Rig: Trucking and the Decline of the American Dream. University of California Press.

Weber, Max. 1905. The Protestant Ethic and the Spirit of Capitalism.

Wherry, F. F. (2012). The culture of markets. Polity.

Wood, Gavin A. and Rachel Ong. 2013. "When and Why Do Landlords Retain Property Investments?" Urban Studies 50(16):3243-61.

Yoon, In-Jin. 2007. On My Own: Korean Businesses and Race Relations in America. Chicago, IL: University of Chicago Press. 


\section{TABLES}

Table 1: Sample breakdown

\begin{tabular}{|c|c|c|c|c|}
\hline & \multicolumn{3}{|c|}{ small investors } & \multirow{2}{*}{$\begin{array}{l}\text { other } \\
\text { respondents }\end{array}$} \\
\hline & random & field & REIA & \\
\hline Dallas & 15 & 2 & 1 & 15 \\
\hline Cleveland & 29 & 16 & 0 & 9 \\
\hline Baltimore & 12 & 5 & 13 & 10 \\
\hline Total & 56 & 23 & 14 & 34 \\
\hline
\end{tabular}

Note: Property managers and corporate owners are categorized as "other respondents"

Table 2: Stated motivation for investment

\begin{tabular}{ll} 
& sample \\
\hline job insecurity/dissatisfaction & $44 \%$ \\
retirement & $18 \%$ \\
general interest in investment & $14 \%$ \\
accidental & $10 \%$ \\
other & $14 \%$ \\
\hline
\end{tabular}

Note: Other includes reasons such as divorce, favor, hobby, and five interviews in which the key motivation could not be determined

Table 3: Percentage of respondents expressing investor ideologies

\begin{tabular}{ll} 
& $\begin{array}{l}\text { small } \\
\text { investors }\end{array}$ \\
\cline { 2 - 2 } & \\
\hline self-sufficiency \& self-employment & $56 \%$ \\
land as material \& anti-elitist & $26 \%$ \\
risk and success & $48 \%$ \\
at least one & $83 \%$ \\
\hline
\end{tabular}

